\author{
THE EFFECT OF PRISON \\ POPULATION SIZE ON CRIME \\ RATES: EVIDENCE FROM PRISON \\ OVERCROWDING LITIGATION
}

Steven D. Levitt

Working Paper No. 5119

\author{
NATIONAL BUREAU OF ECONOMIC RESEARCH \\ 1050 Massachusetts Avenue \\ Cambridge, MA 02138 \\ May 1995
}

I would like to thank Josh Angrist, Austan Goolsbee, Larry Katz, Thomas Marvell, Anne Piehl, James Poterba, Joel Waldfogel, and seminar participants at Harvard, M.I.T., and the NBER Public Economics program for helpful comments and discussions, as well as Thomas Marvell and the American Civil Liberties Union National Prison Project for graciously supplying data. This paper is part of NBER's research program in Public Economics. Any opinions expressed are those of the author and not those of the National Bureau of Economic Research.

(c) 1995 by Steven D. Levitt. All rights reserved. Short sections of text, not to exceed two paragraphs, may be quoted without explicit permission provided that full credit, including $\odot$ notice, is given to the source. 


\title{
THE EFFECT OF PRISON \\ POPULATION SIZE ON CRIME \\ RATES: EVIDENCE FROM PRISON \\ OVERCROWDING LITIGATION
}

\begin{abstract}
Previous studies of the impact of changes in prisoner populations on crime rates have failed to adequately control for the simultaneity between those two variables. While increases in the number of prisoners are likely to reduce crime, rising crime rates also translate into larger prison populations. To break that simultaneity, this paper uses the status of prison overcrowding litigation in a state as an instrument for changes in the prison population. Overcrowding litigation is demonstrated to have a negative impact on prison populations, but is unlikely to be related to fluctuations in the crime rate, except through its effect on prison populations. Instrumenting results in estimates of the elasticity of crime with respect to the number of prisoners that are two to three times greater than previous studies. The results are robust across all of the crime categories examined. For each one-prisoner reduction induced by prison overcrowding litigation, the total number of crimes committed increases by approximately 15 per year. The social benefit from eliminating those 15 crimes is approximately $\$ 45,000$; the annual per prisoner costs of incarceration are roughly $\$ 30,000$.
\end{abstract}

Steven D. Levitt Harvard Society of Fellows 78 Mount Auburn Street Cambridge, MA 02138 and NBER 
The incarceration rate in the United States has more than tripled in the last two decades. At year-end 1994, the United States prison population exceeded one million. Annual government outlays on prisons are roughly $\$ 40$ billion per year. The rate of imprisonment in the United States is three to four times greater than most European countries; among the industrialized countries, only Russia has a higher incarceration rate.

In spite of the record levels of incarceration in the United States, crime rates have continued to rise, as demonstrated in Figure 1. Over the same period during which the incarceration rate more than tripled, the reported rate of violent crime per capita almost doubled, while property crimes per capita rose $25 \%$. Such correlations have led commentators to label the increasing reliance on imprisonment a policy failure, recommending a moratorium on new prison construction, alternative correctional programs, or decriminalization of drug offenses (e.g., Nagel 1977, Rogers 1989, Zimring and Hawkins 1991, Selke 1993).

Clearly, however, one cannot conclude that the increased levels of incarceration have been a failure simply because prison populations and crime have trended together. Holding the prison sentence constant for any given offense, any exogenous shift in crime will lead to a proportional increase in the prison population. To the extent that the underlying determinants of crime, such as gang involvement, the increase in single-parent families (Bane 1986), and the declining availability of legitimate economic opportunities for teenagers (Grogger 1994) have worsened over time, the increased use of prisons may simply be masking what would have been an even greater rise in criminal activity.

Rigorous analysis of the impact of prisons on crime has only recently emerged. One approach to this question is the use of self-reported criminal activity obtained from prisoner 
surveys (Peterson and Braiker 1980, Visher 1986, DiIulio and Piehl 1991, Piehl and Dilulio 1995). The various surveys of prison populations have yielded similar results, the most striking feature of which is the skewness of the distribution. In Wisconsin, for instance, the median prisoner reports involvement in twelve non drug-related crimes per year when not imprisoned; the mean self-report, in contrast, is 141 (DiIulio and Piehl 1991). ${ }^{1}$ Cost-benefit calculations based on prisoner self-reports suggest that the social benefits of incarcerating the median and mean prisoner outweigh the social costs, but that the cost of imprisoning the bottom quartile of inmates outweighs the social benefits (Piehl and DiIulio 1995).

There are, however, a number of risks in using prisoner self reports as a basis for public policy. First, there are the standard problems with survey data reliability, especially when the respondents are convicted criminals. ${ }^{2}$ A second problem with prisoner self-reports is that they capture only the incapacitation effect of prison sentences. To the extent that the length of prison terms will also have both specific and general deterrence effects, the benefits of prisons will be systematically underestimated. ${ }^{3}$ On the other hand, if new criminals fill the vacated market niches, the number of crimes prevented through incarceration will be exaggerated. Finally, it is difficult to determine where in the distribution a particular prisoner falls. Attempts to predict recidivism have generally been unsuccessful, although improved econometric techniques have 1,834 .

1 When drug-related crimes are also included, the median rises to 26 and the mean becomes

2 A large literature surveyed in Spelman (1994) examines the validity of prisoner self reports. There is some evidence that, particularly on the extremes, infrequent offenders underreport criminal activity and frequent offenders exaggerate their criminal involvement. Consequently, the median may be a more reliable estimator than the mean.

3 Ehrlich (1981) and Levitt (1995) find that deterrence effects are substantially larger than incapacitation effects. 
led to greater success (Schmidt and Witte 1987). Without knowing the capability of parole boards for distinguishing between the risks posed by different prisoners, it is impossible to make an informed choice about the optimal scale of imprisonment since the policy implications of releasing the 25 th percentile prisoner differs dramatically from that of the median or mean prisoner.

An alternative approach to measuring the impact of imprisonment on crime rates is to estimate aggregate elasticities (Bowker 1981, Devine et al. 1988, Marvell and Moody 1994). The most relevant of these studies is Marvell and Moody, which uses state-level panel data, obtaining estimates of the elasticity of crime with respect to the prison population of -0.16 , a figure that is consistent with other recent estimates in the literature (Spelman 1994, Wilson 1994). Donohue and Siegelman (1994), using these estimates, conclude that the present scale of imprisonment is approximately optimal from a social cost-benefit perspective.

While the use of aggregate data avoids many of the difficulties inherent in the use of prisoner self-reports, simultaneity bias becomes a critical concern. ${ }^{4}$ Increased incarceration is likely to reduce the amount of crime, but there is also little question that increases in crime will translate into larger prison populations. For instance, if there is no change in the punishment per crime, the prison population will trend one-for-one with changes in the crime rate. Consequently, OLS estimates of the effect of prisons on crime are likely to understate the true

${ }^{4}$ Marvell and Moody (1994) does not attempt to control for simultaneity, instead using the results of Granger tests to conclude that there is little evidence of a short-term impact of crime on state prison populations. 
magnitude of the effect, perhaps dramatically. ${ }^{5}$

The objective of this paper is to obtain estimates of the effect of prison populations on crime that are not affected by the presence of simultaneity. To achieve that goal requires an instrumental variable that is correlated with changes in the size of the prison population, but is otherwise unrelated to the crime rates. The variable employed in this paper is the status of state prison overcrowding litigation. Over the past thirty years, prisoners' rights groups have brought numerous civil suits alleging unconstitutional conditions in prisons. In twelve states, the entire state prison system either is currently or has formerly been under court order concerning overcrowding.

Not surprisingly, as demonstrated in Section I of this paper, the existence of overcrowding litigation reduces the growth rates of prison populations. For example, in the three years prior to the initial filing of litigation in the twelve states where the entire prison system eventually fell under court control, prison population growth rates outpaced the national average by $2.3 \%$ annually. In the three years following the filing of litigation, prisoner growth rates lagged behind the nation as a whole by $2.5 \%$ a year. In the three years after a final court order was handed down, growth rates were $4.8 \%$ below the national average.

It seems plausible, however, that prison overcrowding litigation will be related to crime rates only through its impact on prison populations, making the exclusion of litigation status from the crime equation valid. Two pieces of evidence support this claim. First, tests of

5 This simultaneity is pervasive in empirical research on criminal topics. Estimates of the effect of police on crime, for instance, almost invariably carry an unexpected positive sign (Cameron 1988). Breaking the simultaneity through the use of the timing of mayoral and gubernatorial elections as an instrument for changes in the police force, however, Levitt (1994) finds that police significantly reduce crime rates. 
overidentifying restrictions are consistent with the exogeneity of the instruments across all of the specifications considered. Secondly, changes in litigation status appear to affect crime rates, but not vice-versa. Crime rates in earlier years have no predictive value in determining whether overcrowding litigation will be filed in a state; if this were not the case, the exogeneity of the instruments would be suspect.

The results obtained in this paper suggest that the impact of prison populations on crime is two to three times greater than previous estimates would imply. Prior to instrumenting, I obtain estimates that are actually slightly smaller than those in past research: elasticities of crime with respect to prisoner populations of approximately -0.10 . The IV estimates, in contrast, are much larger in magnitude. For violent crime, elasticities of -0.40 are obtained. For property crime, the elasticities are -0.30 . My estimates imply that each marginal prisoner released as a result of overcrowding litigation is associated with an increase of fifteen crimes per year, almost exactly the self-reported criminal activity of the median prisoner.

Using the estimates of the costs of crime to victims in Cohen (1988) and Miller, Cohen, and Rossman (1993), the marginal social benefit in crime reduction of adding one prisoner for one year is approximately $\$ 45,000$, substantially above the costs of incarceration $(\$ 25,000$ to $\$ 35,000$ per prisoner per year).

The outline of the paper is as follows. Section I provides background information on prison overcrowding litigation. Section II describes the data used in the analysis and establishes a negative relationship between overcrowding litigation and the size of the prison population. A positive reduced-form correlation between overcrowding litigation and crime rates is also demonstrated. Section III estimates a relationship between prison populations and crime, using 
the status of prison overcrowding lawsuits as an instrument. Section IV considers various public policy implications of these estimates. Section $\mathrm{V}$ offers a brief set of conclusions.

\section{Section I: Prison Overcrowding Litigation}

Since the first filing of prison overcrowding litigation on the grounds of cruel and unusual punishment in $1965,{ }^{6}$ similar lawsuits have been brought in forty-seven states and the District of Columbia. The success of plaintiffs in overcrowding litigation has been overwhelming: of the approximately seventy cases brought, at least partial victory has been achieved in all but six. As of January 1, 1993, litigation was pending in twelve states.

Stipulations of court orders on overcrowding vary substantially. Only on rare occasions do judges mandate the release of prisoners to alleviate overcrowding. More frequently, population caps have been imposed, or "double celling" prohibited, with the prison system administrators and state government left with the freedom to determine the means through which compliance will be attained (e.g., construction of new prison facilities, fewer offenders sentenced to prison terms, early release programs, or reallocation of prisoners across institutions). The court frequently judges compliance to be inadequate, leading to the further step of contempt orders, or court-appointed receivers/monitors.

In twelve states, the entire prison system has been under court order concerning overcrowding; in the other states, only a portion of the prison facilities has been affected. Whether the entire state prison system is under court control is likely to be critical in

6 Finney v. Arkansas Board of Correction, 505 F.2d 194 (8th Cir. 1974). A complete summary of litigation can be found in Koren (1993) and other issues of The National Prison Project Journal. 
determining whether such litigation has an impact on overall state prison populations. When only some of the prisons are deemed overcrowded, the state has flexibility in shifting prisoners between facilities and need not adjust the total number of prisoners. ${ }^{7}$

The status of prison litigation in a given state at a particular point in time can be classified into one of six categories: (1) no overcrowding litigation filed, (2) litigation filed, but no decision yet handed down, (3) an initial decision reached, but currently under appeal, (4) a final decision reached, (5) further court action such as the appointment of a monitor, (6) release of the prison system from court supervision. A priori, one would expect categories 2 through 5 to be associated with lower prison growth rates, at least in the short term. ${ }^{8}$ Even before a final decision is handed down, prison systems will have incentives to act strategically, improving prison conditions in an attempt to win more favorable court opinions. The sixth category, release of the prison system from court supervision, is likely to be associated with an increased growth rate in the prison population.

Table 1 identifies the twelve states in which the entire prison system has come under court control, along with the corresponding dates. There is wide variation in the timing of prison overcrowding litigation status across the different states. Final court decisions were handed down as early as 1971 and as late as 1991 . The states falling entirely under court control are disproportionately, but not exclusively, Southern states. Southern states have historically had higher incarceration rates. In 1970, for instance, the prison population per

${ }^{7}$ In contrast, there is little shifting of prisoners across state lines.

${ }^{8}$ Over a time frame in which the states are able to add prison capacity --four to five years-the effect on prison populations is likely to be less pronounced. 
100,000 residents was 125 in the South, 105 in the West, 86 in the North Central, and 70 in the Northeast (Zimring and Hawkins 1991). When litigation was first filed in these twelve states, incarceration rates were on average $34 \%$ greater than the national average.

To the extent that the states where the entire prison system is under court control differ systematically from the rest of the country, the use of cross-state variation is potentially misleading. A number of steps are taken to counteract that possibility. First, all of the analysis in this paper focuses on percent changes in variables, eliminating any effects of differences in levels of crime rates or imprisonment across states. Secondly, in some specifications, state-fixed effects are included to control for the possibility that not only do the levels of the variables differ systematically across states, but also the growth rates. Finally, the possibility that the coefficients systematically differ between Southern and non-Southern states, even after these precautions, is also examined.

Section II: Correlations between Prison Overcrowding Litigation, Prison Populations, and Crime Rates in the Raw Data

The data set used in this paper is a panel of annual, state-level observations, running from 1971-1993.9 Throughout the paper, all incarceration and crime rates are defined on a per capita basis. State prison populations are defined as the number of prisoners serving sentences of at least one year under the jurisdiction of the state prison system, and thus includes inmates in state prisons, state prisoners held in local jails due to overcrowding, and prisoners housed in data.

9 State prison population estimates from before 1971 are not comparable to more recent 
other states due to lack of appropriate facilities within the state borders. Prison populations are computed as a snapshot as of December 31 st.

Data on state crime rates are based on the number of crimes reported to the police over the course of a year, as compiled annually by the Federal Bureau of Investigation in Uniform Crime Reports. Crime data is available for seven individual crime categories: murder and nonnegligent homicide, forcible rape, aggravated assault, robbery, burglary, larceny, and motor vehicle theft. Precise definitions of each of the crime categories are provided in the appendix. The first four crimes are classified as violent crimes; the latter three crimes are denoted property crimes. The use of reported (as opposed to actual) crime rates is a clear source of measurement error. Since crime rates are left-hand-side variables in the analysis, however, such measurement error will not lead to bias in the parameter estimates unless the measurement error is correlated with the right-hand-side variables. ${ }^{10}$

In considering the effects of prison overcrowding litigation, the analysis will focus exclusively on the twelve states in which the entire prison system has come under court supervision. These states will be unable to comply with court orders on overcrowding simply by redistributing prisoners across institutions. In contrast, states in which only a subset of institutions is affected by a court order have much greater flexibility in responding to court mandates. Empirically, I have been unable to uncover any systematic evidence that court orders affecting individual facilities within a state have any impact on overall state prison populations.

10 For instance, a correlation might be expected between the rate of crime reporting and the size of the police force. A larger police force might affect the likelihood that a case is solved, leading victims to report a greater percentage of crimes. Levitt (1995b) finds only weak evidence of such a relationship. 
Prison litigation status is captured by a series of indicator variables corresponding to the six litigation categories described in the previous section. Throughout much of the analysis, only recent changes in litigation status are considered since the effects on prisoner population growth rates are likely to be concentrated in the short run. Table 2 gives summary statistics for all fifty states for the data described above, as well as for additional variables (police employees, economic factors, and demographic controls) used in the analysis.

Table 3 presents state-by-state data on prison population growth rates as a function of prison overcrowding litigation status for the twelve states where the entire court system falls under court jurisdiction. In order to control for national trends in prison populations, the values reported in the table are deviations from the national average growth rates in prison populations for the years in question. In contrast to the analysis that follows, no distinction is made in Table 3 between the short-run and long-run effects of litigation status on prisoner growth rates. For the most part, the expected pattern of coefficients emerges from Table 3, although the effects are not overwhelmingly large. In three-quarters of the cases, growth rates in state prison populations outpaced national growth rates prior to the filing of litigation. Across all cases, the pre-filing annual growth rate in prisoners in these states was $4.2 \%$ above the national mean. In stark contrast, after the filing of litigation, prisoner growth rates fell below the national average in nine of ten states, with a mean of $-2.4 \%$ annually. The impact of actual court actions emerges less clearly. Growth rates were slightly above the national average after preliminary court decisions were handed down, but were slightly below the nation as a whole after final decisions were reached and after further court actions were taken. As expected, prisoner populations grow more quickly after the courts release control, although only three states fall 
into that category. Of the forty-six state-by-state values listed in the table, 30 carry the expected sign. Assuming independence across those observations, that pattern of observations would be expected to occur by chance less than $3 \%$ of the time.

It may be unreasonable to expect prison overcrowding litigation to have long-run effects on growth rates in prison populations. More likely, overcrowding litigation has only a short-run effect on prison population growth rates, after which normal growth rates resume, although starting from a lower base than otherwise would have been the case. ${ }^{11}$ Table 4 isolates the short-run effects of changes in overcrowding litigation status on prisoner growth rates. The data is broken down according to status changes during a particular year, and changes two to three years directly after a status change. ${ }^{12}$ Column 1 displays the number of observations falling into a given category; column 2 shows annual prisoner growth rates relative to the national average. The pattern of coefficients in column 2 is similar to that of Table 3 , but the short-run effects are substantially larger in magnitude than the long-run effects, supporting the view that

11 Therefore, unless "catching up" in prison populations occurs in later periods, the long-run level of the prison population will be lower as a consequence of overcrowding litigation.

12 The litigation status categories are defined so as to be mutually exclusive. For example, assume that a case is filed in 1980, a preliminary decision handed down in 1984, and a final decision made in 1985 . In 1980, the litigation status would be "filed, year of status change." In 1981 and 1982, the litigation status would be "filed, two to three years following a status change." In 1983, the litigation status would be "none of the above," since the last status change was more than three years previous. In 1984, litigation status would be "preliminary decision, year of status change." Because the final decision is handed down the next year, 1985 would be "final decision, year of status change." 1986 and 1987 would be classified as "final decision, two to three years following a status change." Later years would be classified as "none of the above," unless further court action was taken. 
the bulk of the effects of overcrowding litigation accrue in the short run. ${ }^{13}$ As before, prison populations grow more quickly than the national average before filing. The number of prisoners continues to grow unabated in the first year of filing ( $2.7 \%$ above national average), but then drops sharply in the two years following initial filing (5.1\% below the national average). Preliminary court decisions appear to have little effect, either initially or with a lag. Final court decisions, however, have a substantial effect, both initially $(-5.1 \%)$ and in the following two years $(-4.6 \%)$. In the three years after a final court order affecting the entire prison system, therefore, prisoner population growth is almost $15 \%$ below the rest of the nation. Since incarceration rates grew at approximately $6 \%$ per year on average during the sample period, this implies that prison populations are almost flat after final decisions. Further court actions have an initial limiting effect on prison populations, but that change is largely undone in the two years that follow. Release from court supervision leads to an immediate jump in prisoners, but no lagged effect.

If changes in overcrowding litigation status are truly exogenous shifters of the prison population, then a comparison of the patterns of prisoner population growth and changes in the crime rate under the different litigation categories should provide a rough measure of the effects of prison populations on crime. Columns 3 and 4 of Table 4 report changes in violent and property crime rates relative to the nation as a whole. ${ }^{14}$ If decreases in the prison population

13 In fact, beyond three years, for the five litigation categories where one would expect prison population rates to be reduced, growth rates are actually $1.0 \%$ above the national average, suggesting that some catching up is occurring in the longer run.

14 The changes in crime rates correspond to the calendar year following the change in status. That is, if a final court decision is handed down in July 1990, the percent change in the crime rate is computed as $\left(\mathrm{crime}_{1991}\right.$-crime $\left._{1990}\right) /$ crime $_{1990}$. To the extent that some of the increase 
have a large impact on crime rates, then one would expect the sign of the values in columns 3 and 4 to be the opposite of those in column 2. That pattern of opposite signs holds true in all eleven categories for both violent and property crimes, a fact that is somewhat remarkable given the small number of observations used in constructing Table $4 .^{15}$ This result, while merely suggestive, foreshadows the large elasticities that will be obtained when litigation status is used as an instrument.

Table 5 reproduces the analysis of Table 4, adding a wide range of covariates including year dummies, economic factors, percent changes in police staffing, and changes in demographic factors such as racial composition and the age distribution, and year dummies. ${ }^{16}$ The omitted litigation status categories are more than three years prior to filing or more than three years since a status change, so all coefficients are relative to those categories. All regressions in Table 5 are estimated using ordinary least squares, with White-heteroskedasticity consistent standard errors in parentheses. Even-numbered columns also include state-fixed effects, which allow for

in crime may come in the second half of 1990 , this measure may understate the true change in the crime rate.

${ }^{15}$ In contrast, this negative relationship between prisoner growth rates and changes in crime rates does not emerge in the sample more generally. Of the approximately 1,000 state-year observations, in $51.1 \%(54.4 \%)$ of the cases are the signs on changes in prisoners and violent (property) crime rates opposite. The contrast between those numbers and the results in Table 4 suggest both that endogeneity is a problem in the data and that prison litigation status is breaking the endogeneity.

16 Data on age distributions within a state are from Marvell and Moody (1994).. Data on police employees are the total number of public police FTEs (including both municipal police and state troopers) in a state, published annually by the Department of Justice. All other variables are available in the Statistical Abstract of the United States. Income and unemployment data vary annually. In contrast, both the percent of a state's population that is black and that resides in a metropolitan area are linearly interpolated from figures reported in the decennial censuses. 
growth rates of the key variables to systematically differ across states. There are some scenarios in which inclusion of state-fixed effects are appropriate, even though the dependent variable is already in terms of percent changes. For instance, if all states are converging to similar incarceration rates in the long run, but Southern states had higher rates at the beginning of the sample, then one might expect slower growth rates in prisoners in Southern states in sample.

Similar patterns continue to emerge after adding covariates. In columns 1 and 2 , only one coefficient changes sign from Table 4. The largest impacts on prison populations continue to be associated with final court decisions and (with a one-year lag) initial filing. Slightly less than half of the status change indicators are individually statistically significant from zero. More importantly, however, the status change indicators are jointly significant at the .001 level. The null hypothesis of equal effects of status changes in the current year and the two following years is rejected at the .05 level in both columns 1 and 2 , suggesting that classifying the observations in this manner is a useful characterization of the data. ${ }^{17}$

Columns 3-6 present estimates of reduced-form correlations between litigation categories and crime rates. Crime rates continue to move in the opposite direction of prisoner populations with only a few exceptions. For instance, in the three years following the court's handing down a final decision, prison populations are estimated to grow a total of $13.7-19.7 \%$ more slowly than if there had been no litigation, while violent crime rates are $11.2-11.6 \%$ higher, and property crime rates are $6.2-6.4 \%$ higher.

If prison overcrowding litigation provides an exogenous source of variation in prison

17 Tests for significance of further lags of litigation changes could not reject the null hypothesis of no effect on prison population growth rates. That result provides more evidence that changes in overcrowding litigation status only affect prisoner growth rates in the short-run. 
populations, changes in crime rates should not be driving changes in litigation status. Put another way, information about whether litigation will be filed in the future should not be related to current crime rates (see, for instance, Model 1993). The coefficient on the litigation status indicator "will file within three years," presented in the top row of Table 5, allows a test of that prediction. Consistent with the claim that the timing of litigation filing is orthogonal to changes in the crime rate, the coefficients in columns 3-6 are both substantively small and statistically insignificant. ${ }^{18}$

Section III: Estimates of the Elasticity of Crime with Respect to Prisoner Populations

Having demonstrated in the previous section a relationship between prison overcrowding litigation and prison population growth rates, as well as a reduced-form relationship between such litigation and changes in crime rates, this section applies instrumental variable techniques to estimate elasticities of crime with respect to prisoner populations.

It is assumed that percent changes in crime rates and prison populations are determined according to

18 While not directly testable, it is also possible that the timing of later changes in litigation status, e.g. the handing down of a final decision, are endogenously related to changes in crime rates. To the extent that endogeneity exists, serial correlation in changes in crime rates will exacerbate the problem. A large jump in crime may trigger a judge to hand down a final decision. Crime rates will continue to be high in the ensuing years due to serial correlation, inducing a spurious relationship between litigation status changes and crime rates. Fortunately, there is little serial correlation in changes in crime rates (once the national trend is removed, the serial correlation in state-level changes in violent (property) crime is .033 (.039)), lessening concern on this score. 


$$
\begin{aligned}
& \% \Delta C R I M E_{s t}=\beta \% \Delta P R I S O N_{s t}+X_{s t}^{\prime} \theta+\gamma_{t}+\epsilon_{s t} \\
& \% \Delta P R I S O N_{s t}=L I T S S T A T_{l t} \delta_{l}+X_{s t}^{\prime} \lambda+\gamma_{t}^{\prime}+\eta_{s t}
\end{aligned}
$$

where the subscript $s$ corresponds to states, $t$ indexes years, and $l$ denotes the various prison litigation categories. $C R I M E_{s t}$ and $P R I S O N_{s t}$ are the relevant per capita crime and incarceration rates, $\mathrm{X}_{\mathfrak{x t}}$ is a vector of covariates, LIT_STAT $_{\mathrm{lst}}$ is a series of indicator variables corresponding to prison litigation status, and $\gamma_{t}$ is a vector of year dummies. In some cases, state-fixed effects are also included in both equations. Because both crime rates and prisoner populations are in terms of percent changes, $\beta$ is an elasticity. The prisoner equation, which represents the firststage equation in two-stage least squares, is identical to that which was estimated in the first two columns of Table 5.

It is likely that the number of prisoners is positively correlated with the residuals of the crime equation, potentially inducing a positive bias in estimates of $\beta$. If the exclusion of prison litigation status from the crime equation is valid, however, two-stage least squares estimation using the litigation status as instruments will lead to consistent estimates.

Table 6 presents estimates of the crime equation separately for violent crimes and property crimes using the same data set and covariates described in the preceding section. In columns 1 and 4, OLS coefficients, which do not control for the endogeneity of prison populations, are presented. In the other columns, indicator variables corresponding to litigation status changes are used as instruments for $\% \triangle P R I S O N$. For each of the five litigation categories, separate indicators are employed for the year of a status change, and the two years 
following a status change, yielding a total of ten instruments. ${ }^{19}$ Columns 3 and 6 also include state-fixed effects. Feasible generalized least squares is employed in the IV regressions to allow for heteroskedasticity across states.

When prison populations are treated as exogenous in columns 1 and 4, the estimated elasticity of crime with respect to prisoners is -0.099 for violent crime and -0.071 for property crime. In both cases, the estimates are quite precise. These elasticities are roughly consistent, but somewhat smaller, than previous estimates in the literature, which have typically been in the neighborhood of -0.10 to -0.20 (Marvell and Moody 1994, Spelman 1994).

Instrumenting for the prison population has a pronounced effect on the estimated elasticities. The estimated elasticities for violent crime in columns 2 and 3 are -0.424 and 0.379 respectively, four times greater than without instrumenting. While the estimates are much less precise due to instrumenting, they are nonetheless statistically different from zero. The increases for property crimes (columns 5 and 6 ) are also substantial; instrumenting leads to estimates of -0.321 and -0.261 , again almost four times higher than the uninstrumented case. The standard errors once again increase, but the estimates are precise enough to attain statistical significance at the .05 level. Prisoners per capita increased by $272 \%$ in the United States between 1971 and 1993. Assuming that the instrumented elasticities obtained here are generalizable to the nation as a whole, violent crime would be twice as high today had the

19 The results presented below have also been replicated not differentiating between the year of a status change and the following two years with very similar point estimates, but larger standard errors. I opt for the larger set of instruments both because an F-test of equal effects in the year of a status change and the following two years is rejected in the first stage (see Table 5 ), and because the likely consequence of choosing a set of instruments that is too large is to induce a bias in the direction of OLS, which does not appear to arise moving from five to ten instruments. 
increase in prisoners not occurred, and property crime would be more than $80 \%$ more frequent.

The other parameters of the model, while also of interest, generally yield mixed and imprecise coefficients. Increases in per capita income are positively correlated with violent crime, but are not strongly related to property crime. The reverse holds true with changes in the unemployment rate. Each one-point change in state unemployment rates leads to an increase of slightly less than $0.5 \%$ in violent crime and a $1 \%$ increase in the property crime rate.

Changes in the number of police are weakly positively correlated with changes in the crime rate, a finding that is common in studies such as these (see Cameron 1988 for a survey). The most likely explanation for that result is endogeneity of police hiring: when crime worsens, the public policy response is to hire more police. ${ }^{20}$ The percent of the population that is Black and the percent residing in metropolitan areas are generally statistically insignificant and switch signs across specifications. In all cases, an increase in the fraction of the population between the ages 15 and 34 is related to higher crime rates. Somewhat surprisingly, the greatest impact comes from the 25-34 age range. The age coefficients are imprecisely estimated, however, making it difficult to draw strong conclusions.

20 Following Levitt (1994), an attempt was made to instrument for changes in the police force using the timing of state elections. Levitt (1994) finds that police hiring in the nation's largest cities is disproportionately concentrated in mayoral and gubernatorial election years, and exploits that fact to estimate the effect of police on crime. Electoral cycles in police hiring, however, are much less pronounced outside of large cities, possibly because crime is a less critical political issue. Consequently, the first-stage correlations between overall state police and gubernatorial elections, while positive, is weak. Instrumenting for police with gubernatorial elections had little impact on the estimated effects of prison population on crime. The elasticity of violent crime with respect to the prison population is -0.37 ( $\mathrm{SE}=0.17$ ); for property crimes the elasticity is $-0.22(\mathrm{SE}=0.10)$ The coefficient on $\% \Delta$ in police becomes negative in the violent crime equation (an elasticity of $-0.44(\mathrm{SE}=.36)$, but remained positive, $0.09(\mathrm{SE}=0.18)$ in the property crime equation. Eliminating the police variable from the equation entirely has little effect on the prisoner coefficients. 
Given the dramatic change in the estimated effects of incarceration in the instrumented regressions, and the fact that these estimates are two to three times greater than conventional wisdom on the subject would predict, special scrutiny of the results is warranted. In the following paragraphs, three separate issues are considered: the validity of the instruments, the robustness of the results, and the generalizability of the findings.

Because the number of instruments exceeds the number of endogenous variables, it is possible to test the overidentifying restrictions on the excluded instruments. The test statistic is calculated as $N^{*} R^{2}$, where $N$ is the number of observations and $R^{2}$ is the $R^{2}$ from a regression of the residuals of the crime equation on all of the exogenous variables, including the instruments. The test statistic is distributed $\chi^{2}$ with degrees of freedom equal to the number of overidentifying restrictions, in this case nine. The P-values for this test are presented in the bottom row of Table 6 . In all cases, the test statistic is well within conventional bounds, supporting the claim of exogeneity of the instruments. ${ }^{21}$

The results presented here appear to be robust to a variety of alternative specifications. The point estimates rise slightly when the demographic, economic, and age variables are removed (elasticities of violent crime with respect to prison population size of -0.50 to -0.42 , and -0.40 to -0.26 for property crime). I have also experimented with estimation in log-levels rather than differences and obtained similar results. Perhaps the strongest evidence that the

21 Creating ten separate instruments out of the litigation status variable may predispose the overidentification test towards acceptance of the exogeneity of the instruments. When the ten instruments are reduced to five by eliminating the distinction between the year of the status change and the following two years, the p-values on the test of overidentifying restrictions range between .104 and .427 across the columns of Table 7, still within acceptable bounds in all instances. 
results are authentic comes from disaggregating the crime data into individual crime categories. Table 7 presents crime-by-crime estimates of specifications corresponding to columns 3 and 6 of Table $6{ }^{22}$ The bottom row of Table 7 also presents the uninstrumented coefficient on the prison variable for comparison purposes. The estimates across the seven crime categories are consistent with the earlier results. The estimated elasticities with respect to prison populations range from -0.147 to -0.703 . Because of large standard errors, only two of the seven estimates are statistically significant at the .05 level, with two others significant at or around the .10 level. In all seven cases, instrumenting leads to more negative estimates. Tests of overidentifying restrictions are safely within accepted bounds for each crime category. Assault, robbery, and burglary are the two crimes most responsive to increases in imprisonment.

A final consideration in interpreting the instrumented coefficients is whether such estimates are generalizable to the full set of states, or to other potential changes in imprisonment policy. When instrumenting, the parameters are identified solely based on variation in prison populations in states where the entire prison system falls under court control. These states tend to be disproportionately Southern and have higher initial incarceration rates. One might consequently expect that the marginal prisoner is less criminal in such states, implying larger elasticities for other states. On the other hand, it is possible that states that rely on higher levels of incarceration are self-selected; they imprison more criminals precisely because incarceration has a greater crime reducing impact in these states. As a test of whether either of those scenarios appears to hold true, the coefficient on prisoners was allowed to vary (in the

${ }^{22}$ The results presented in Table 7 do not allow for correlation in errors across the different crime categories. The results are similar when the seven crime categories are jointly estimated, allowing for cross-crime correlations in the errors. 
uninstrumented regressions) according to whether or not a state is Southern. The estimated elasticities were somewhat lower in Southern states. For violent crime, the elasticities were $0.016(\mathrm{SE}=0.063)$ and $-0.118(\mathrm{SE}=0.035)$ respectively; for property crime, the elasticities were $-0.034(\mathrm{SE}=0.035)$ and $-0.081(\mathrm{SE}=0.020)$. In neither case, however, could the null hypothesis of no difference in the coefficients across Southern and non-southern states be rejected at the .05 level. If the marginal impact of increased incarceration on crime is actually lower in Southern states, the estimates of this paper will tend to understate the true benefits of increased imprisonment in the nation as a whole..$^{23}$

Perhaps the more pressing question of applicability for the estimates in this paper concerns whether prison population changes that are court-ordered are similar to other sources of variation in prison populations. An important observation with respect to this issue is that all of the reduction in prison populations due to overcrowding litigation appears to be due to early release of prisoners. The litigation indicator variables have essentially no explanatory power with respect to the number of prisoners committed to the prison system on the front end. Thus, the estimates presented here are likely to be most applicable to changes in policies affecting time served, such as parole policies. The court only rarely mandates the release of prisoners, instead taking actions such as enjoining double bunking or closing portions of prisons, which must then be resolved by the state prison systems. Consequently, court-ordered

${ }^{23}$ As an additional check, the sample was also divided according to whether or not a state's entire prison system eventually fell under court control. For both violent and property crime, the point estimates on the effect of prison populations on crime were nearly identical across the two sets of states: $-0.068(\mathrm{SE}=0.047)$ vs. $-0.099(\mathrm{SE}=0.033)$ for violent crime; -0.081 $(\mathrm{SE}=0.029)$ vs. $-0.079(\mathrm{SE}=.019)$ for property crime. Again, in neither case can the null hypothesis that the two sets of states have equal coefficients be rejected. 
fluctuations in prisoners may in fact be quite similar in their impact to other sources of variation in prison populations.

\section{Section IV; Policy Implications of the Estimates}

In order to use the results of the previous section in formulating public policy, estimates of the social costs of crime are required. The estimates of Cohen (1988) and Miller, Cohen, and Rossman (1993) are used for that purpose. Those papers attempt to capture both monetary costs of crime (medical bills, property loss, lost productivity) and quality of life reductions caused by pain and suffering. To gauge the quality of life reductions, jury awards in civil suits, excluding punitive damages, are estimated for a wide range of injuries. Those awards are then mapped to the distribution of injuries associated with the various crime categories. The cost estimates do not include the additional preventative measures taken by victims, lifestyle changes associated with the marginal crime, costs to employers, or legal costs, and therefore may understate the true costs of crime. On the other hand, the cost estimates correspond to the average crime, which may be more serious than the marginal crime, and therefore may exaggerate the costs of crime.

Another consideration in interpreting the estimates of the previous section in a policy context is the extent to which the results obtained using reported crimes carry over to unreported crimes. This question is important since victimization surveys suggest that only $38 \%$ of all index crimes are reported to the police. Even serious crimes such as robbery are reported little more than half of the time. In what follows, it is assumed that the elasticity of unreported crime to the number of prisoners is identical to that for reported crime. To the extent that criminals 
do not know in advance whether a crime will be reported, this seems to be a reasonable assumption. ${ }^{24}$

Table 8 presents the estimated impact of adding one prisoner at the margin for a jurisdiction that is at the 1993 national average for all variables. ${ }^{25}$ The values in Table 8 are based on the crime-by-crime point estimates presented in Table 7. Column 1 is the number of reported crimes reduced annually for each additional prisoner. Column 2 reflects the combined reduction in reported and unreported crime using reporting rates from the National Crime Survey (U.S. Department of Justice 1992).

According to column 1, each additional prisoner leads to a reduction of between five and six reported crimes. Including unreported crimes raises the total to fifteen. Each additional prisoner eliminates 0.004 murders annually, one-twentieth of a rape, and between two and three other violent crimes. The bulk of the crime reduction, however, is in the less socially costly property crimes.

The estimate of fifteen crimes eliminated per prisoner per year is remarkably close to the median number of crimes obtained from surveys of prisoner self-reports, which have ranged

24 It is possible that reported and unreported crimes differ systematically. For instance, crimes perpetrated by strangers are more likely to be reported. The fact that the criminal is in prison might be a signal that the criminal has a propensity to commit crimes that get reported.

${ }^{25}$ Because the relationship between prisoners and crime is estimated as an elasticity in this paper, the effect of an additional prisoner depends on the number of prisoners relative to the amount of crime. Prison population growth has outpaced increases in the crime rate over the last twenty-five years. Consequently, the estimated social benefit of adding one prisoner is substantially lower (almost $40 \%$ ) when evaluated at 1993 means vis-a-vis the mean of the entire sample. When considering the implications for current public policy, use of 1993 means seems most appropriate. My use of 1993 means also explains why the number of crimes attributable to the marginal prisoner is similar to that reported in Table 5 of Marvell and Moody (1994), despite the fact that my estimated elasticities are much larger. 
from 12 to 15 (Peterson and Braiker 1980, Dilulio and Piehl 1991, Piehl and DiIulio 1995). The similarity between the two sets of results does not necessarily imply that the marginal prisoner is also the median prisoner since prisoner surveys only take into account incapacitation effects of prison, and also do not capture replacement effects when one criminal is arrested. In contrast, the estimates of this paper incorporate incapacitation, replacement, and deterrence effects.

Columns 3 and 4 are the Cohen (1988) and Miller, Cohen, and Rossman (1993) estimates of the monetary and quality of life losses due to crime. ${ }^{26}$ For violent crimes, the bulk of the costs are associated with quality of life reductions. For property crimes, the costs are almost exclusively monetary. Column 5 combines the information in the second, third, and fourth columns to provide an estimate of the social benefit of crime reduction. The largest social benefits are associated with reduced assaults and robberies, together accounting for over $\$ 30,000$ per prisoner per year. No other type of crime reduction yields a social benefit greater than $\$ 5,000$. The reduction in larcenies, though far and away the largest in raw numbers, carries the smallest social benefit across the crime categories. Combining all of the crime categories,

${ }^{26}$ The Miller, Cohen, and Rossman (1993) estimates, which update Cohen (1988), are only available for violent crimes. I diverge from Miller, Cohen, and Rossman (1993) in the determination of the cost of a murder. According to their estimates, the cost per murder (adjusted to 1992 dollars) is over $\$ 2.7$ million. More than $\$ 700,000$ of that value is lost productivity. Following Schelling (1989), however, I do not include that value since the victim would have been the primary consumer of that lost productivity, and therefore that society loses on net. The value Miller, Cohen, and, Rossman (1993) assign to lost quality of life per murder, almost $\$ 2$ million, also seems too high. Therefore, I (somewhat arbitrarily) assign a quality of life reduction of $\$ 400,000$ per murder. It is, of course, straightforward to calculate social benefits to crime reductions under alternative valuations that the reader deems more appropriate. 
incarcerating one additional prisoner yields a social benefit of $\$ 44,900$ annually. ${ }^{27}$

Estimates of the annual taxpayer cost of incarcerating vary within a relatively narrow range. Dilulio and Piehl (1995) use $\$ 25,000$ per prisoner per annum as a "widely asserted" benchmark. $^{28}$ Waldfogel (1993) calculates the annual cost of locking up a prisoner to be $\$ 27,350$. Zedlewski (1987) arrives at a figure of $\$ 32,000$. Donohue and Siegelman (1994), correcting apparent flaws in the approach of Cavanaugh and Kleiman (1990), estimate the cost to be $\$ 35,620$.

A simple comparison of the estimated costs and benefits of incarceration presented above suggests that the United States is currently below the socially optimal level of imprisonment. Given the uncertainties of measurement, however, this conclusion must be viewed as highly tentative. There are many factors omitted from the calculation of both costs and benefits. The cost estimates generally do not factor in tax-induced distortions that make the social cost of raising a dollar greater than a dollar, ${ }^{29}$ nor do they include the pain and suffering of prisoners and their families, or the possible adverse effect of prison on post-prison wages (Lott 1992, Waldfogel 1994). The social benefit estimates are only computed based on the seven crimes examined in this paper, and thus ignore the benefits of reductions in many other illegal activities,

27 To get a rough estimate of the precision of the aggregate social benefit total of $\$ 44,900$, a standard error was computed, assuming that the costs per crime were exact and the point estimates across the different crime categories were uncorrelated. Both of those assumptions will lead the computed standard error to understate the true value. Given those assumptions, the estimated standard error on the social benefit per marginal prisoner is $\$ 6,700$.

${ }^{28}$ Roughly confirming this estimate, they cite Bureau of Justice Statistics figures that prison operating costs are slightly below $\$ 16,000$ per prisoner per annum.

${ }^{29}$ Feldstein (1995) suggests that the deadweight loss associated with raising marginal federal funds may be much higher than previously thought. 
including drug offenses, arson, fraud, and driving under the influence.

A further caveat concerning the results of this paper is that the social benefit of radically expanding the prison population through the incarceration of increasingly minor criminals is likely to be well below the estimates presented here. Given the apparent skew in the distribution of criminal activity, the current group of prisoners is likely to be much more criminally active than the marginal pool of individuals that come into contact with the criminal justice system but are not imprisoned.

\section{Section V: Conclusions}

Using prison overcrowding litigation as an instrument for changes in the prison population, this paper attempts to estimate the marginal productivity of increased incarceration in reducing crime. The estimates obtained are two to three times larger than the conventional wisdom. The results are robust across all of the crime categories examined. Incarcerating one additional prisoner reduces the number of crimes by approximately 15 per year, a number in close accordance with the level of criminal activity reported by the median prisoner in surveys. While any cost-benefit analysis is dependent on many questionable assumptions, the estimates presented in this paper suggest that the marginal costs of incarceration are below the accompanying social benefits of crime reduction.

The finding that prisons appear cost-beneficial does nothing to reduce the importance of identifying and correcting those factors that lie at the source of criminal behavior. Toward that end, Donohue and Siegelman (1994) survey a number of early-childhood and family-intervention programs that have achieved encouraging results in small samples but have not yet been 
attempted on a larger scale. While labor market interventions have generally not been successful in this realm, the Job Corps appears to be a possible exception (Donohue and Siegelman 1994). Finally, recent experimentation with alternatives to traditional prisons, including communitybased sentences and "boot camps," represents an important avenue of investigation. 


\section{Figure}

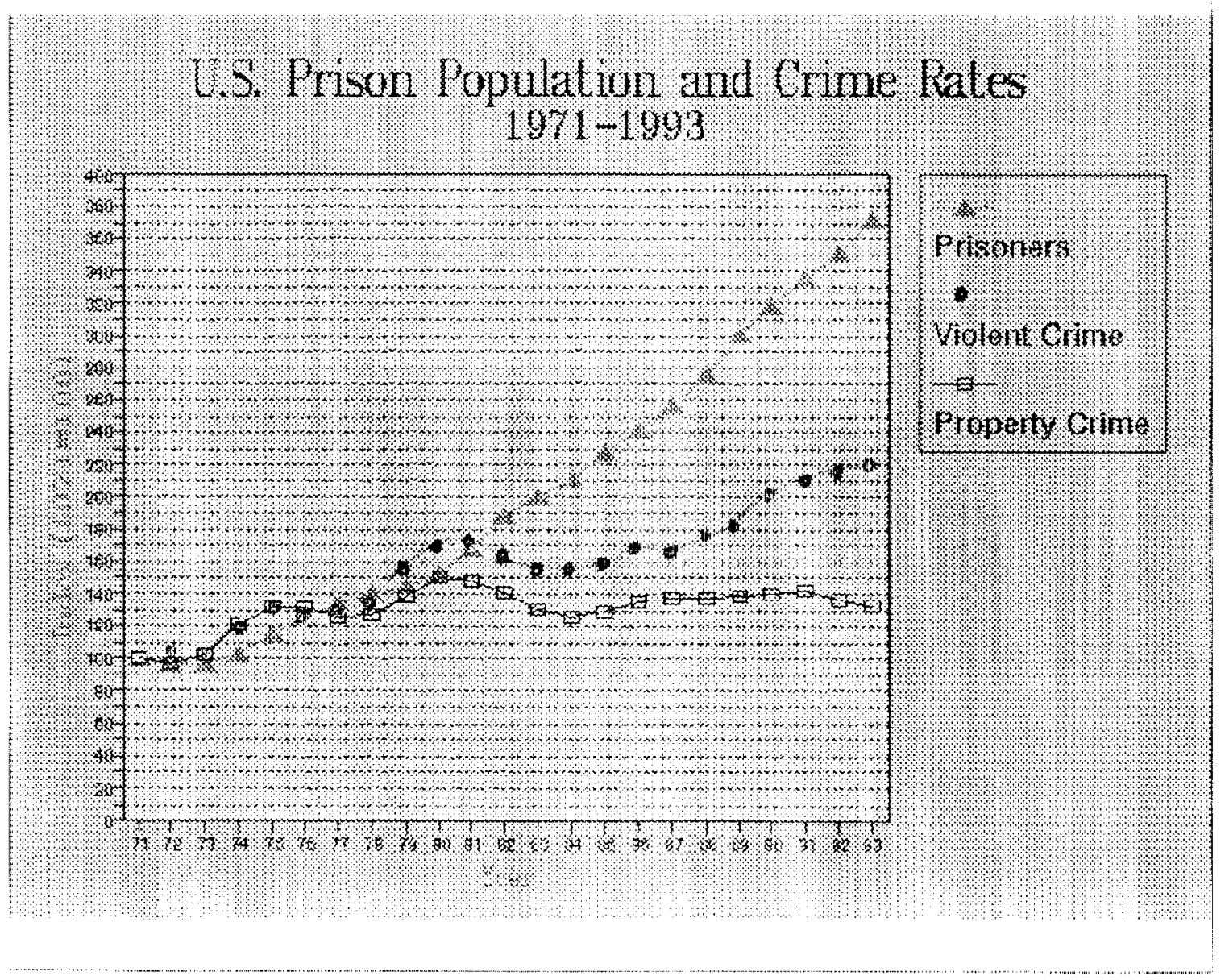


Table 1: Prison Overcrowding Litigation Status 1971-1993

States with Entire System Under Court Order

\begin{tabular}{|c|c|c|c|}
\hline Filing & Filed & $\begin{array}{l}\text { Prelim. } \\
\text { Decision }\end{array}$ & $\begin{array}{l}\text { Final } \\
\text { Decision }\end{array}$ \\
\hline
\end{tabular}

$\begin{array}{lcccccc}\text { Alabama } & 71-73 & 74-75 & 76-77 & 78 & 79-83 & 84-93 \\ \text { Alaska } & 71-85 & 86-89 & ----- & 90-93 & ----- & ----- \\ \text { Arkansas } & ----- & ----- & ----- & 71-73 & 74-81 & 82-93 \\ \text { Delaware } & 71-87 & ----- & ---- & 88-91 & 92-93 & ----- \\ \text { Florida } & 71 & 72-74 & 75-76 & 77-79 & 80-93 & ----- \\ \text { Mississippi } & ----- & 71-73 & ---- & 74-93 & ---- & ---- \\ \text { New Mexico } & 71-76 & 77-79 & 80-89 & 90 & 91-93 & ----- \\ \text { Oklahoma } & 71 & 72-76 & ---- & 77-85 & ----- & 86-93 \\ \text { Rhode Island } & 71-73 & 74-76 & ----- & 77-85 & 86-93 & ----- \\ \text { South Carolina } & 71-81 & 82-84 & 85-90 & 91-93 & ---- & ---- \\ \text { Tennessee } & 71-79 & 80-81 & ----- & 82-84 & 85-93 & ---- \\ \text { Texas } & 71-77 & 78-79 & 80-84 & 85-91 & 92-93 & ----\end{array}$

Notes: Categories of litigation status are defined as follows. Pre-filing: No prison overcrowding litigation filed in the state. Filed: Litigation filed, but no court decision. Preliminary Decision: A court decision has been handed down, but is under appeal. Final Decision: Court decision handed down, no further appeals. Further Action: Subsequent court intervention on the issue of overcrowding, including appointment of special monitors, contempt orders. Released by Court: Dismissal of case or relinquishing of court's oversight of prisons. The twelve states included in the table reflect all states that have had their entire prison system under court order concerning overcrowding at some point between 1971-1993. Litigation status in a particular year based on information reported in the ACLU National Prison Project Journal (multiple issues) and the court opinions cited therein. 
Table 2: Summary Statistics

All variables except percentages per 100,000 residents

\begin{tabular}{|c|c|c|c|c|}
\hline Variable & Mean & $\begin{array}{r}\text { Standard } \\
\text { Deviation }\end{array}$ & $\underline{\text { Minimum }}$ & Maximur \\
\hline Prison Population & 168.1 & 130.7 & 20.3 & $1,541.2$ \\
\hline Violent Crime & 446.5 & 303.1 & 38.0 & $2,921.8$ \\
\hline Murder & 7.8 & 6.5 & 0.6 & 81.1 \\
\hline Rape & 30.9 & 15.1 & 4.1 & 100.7 \\
\hline Assault & 255.9 & 158.8 & 25.0 & $1,557.6$ \\
\hline Robbery & 151.9 & 158.8 & 6.5 & $1,675.8$ \\
\hline Property Crime & $4,408.2$ & $1,277.7$ & $1,255.8$ & $8,839.3$ \\
\hline Burglary & $1,206.2$ & 422.8 & 338.8 & $2,907.9$ \\
\hline Larceny & $2,799.5$ & 817.1 & 762.7 & $5,449.0$ \\
\hline $\begin{array}{l}\text { Motor Vehicle } \\
\text { Theft }\end{array}$ & 402.5 & 229.1 & 83.2 & $1,590.2$ \\
\hline \multicolumn{5}{|l|}{$\begin{array}{l}\text { Prison Overcrowding } \\
\text { Litigation Status }\end{array}$} \\
\hline $\begin{array}{l}\text { Not Filed/only } \\
\text { Partial Coverage }\end{array}$ & 0.827 & 0.378 & 0.0 & 1.0 \\
\hline Filed & 0.026 & 0.158 & 0.0 & 1.0 \\
\hline Preliminary Decision & 0.021 & 0.144 & 0.0 & 1.0 \\
\hline Final Decision & 0.057 & 0.232 & 0.0 & 1.0 \\
\hline $\begin{array}{l}\text { Further Court } \\
\text { Action }\end{array}$ & 0.043 & 0.204 & 0.0 & 1.0 \\
\hline $\begin{array}{l}\text { Released from } \\
\text { Court Control }\end{array}$ & 0.026 & 0.158 & 0.0 & 1.0 \\
\hline Police Employees & 259.5 & 88.4 & 130.8 & 907.9 \\
\hline GNP per capita & $16,398.9$ & $3,125.9$ & $9,728.8$ & $29,004.0$ \\
\hline Unemployment Rate & 0.066 & 0.021 & 0.022 & 0.180 \\
\hline \multicolumn{5}{|l|}{$\begin{array}{l}\text { Demographic Variables } \\
\text { (percent of population) }\end{array}$} \\
\hline Black & 0.108 & 0.133 & 0.002 & 0.922 \\
\hline Metro Areas & 0.637 & 0.230 & 0.145 & 1.000 \\
\hline Age $0-14$ & 0.237 & 0.030 & 0.163 & 0.342 \\
\hline Age 15-17 & 0.051 & 0.008 & 0.026 & 0.069 \\
\hline Age 18-24 & 0.122 & 0.014 & 0.085 & 0.159 \\
\hline Age 25-34 & 0.161 & 0.020 & 0.101 & 0.236 \\
\hline
\end{tabular}

Notes: Observations are annual state-level data, 1971-1993. Where applicable, values in table are per 100,000 residents. Prison overcrowding litigation categorizations are mutually exclusive. Those states whose entire prison system has never come under court order are categorized under the prison overcrowding litigation category not filed/only partial coverage. Prison population data, crime statistics, and age breakdowns are from Marvell and Moody (1994). Prison overcrowding litigation status based on information reported in the ACLU National Prison Project Journal (multiple issues) and the court opinions cited therein. Police employee data are full-time equivalents, and are published annually by the department of Justice. Economic data is annual, state-level data taken from the Statistical Abstract of the United States. Percent Black and percent residing in metropolitan areas are linear interpolations of decennial census data, as reported in the Statistical Abstract. 
Table 3: Effect of Prison Overcrowding Litigation on Prison Populations

Annual Deviation from National Average

Prison Overcrowding Litigation Status

Pre-

Prelim.

Final

Further

Released

Filing

Filed

Decision

Decision

Action

by Court

Alabama

$-2.1 \%$

$-1.1 \%$

$7.0 \%$

$-14.5 \%$

$3.2 \%$

$-0.3 \%$

Alaska

5.1

$-2.1$

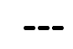

1.5

Arkansas
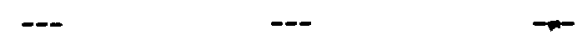

$-0.7$

0.1

0.4

Delaware

8.6

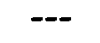

$-$.

$-5.2$

0.2

Florida

$-1.3$

10.4

$-4.4$

$-2.2$

Mississippi

$-3.9$

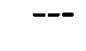

1.3

New Mexico

\section{4}

$-1.0$

$-1.4$

$-8.8$

$-3.5$

Oklahoma

$-6.5$

0.7

3.4

Rhode Island

\section{4}

$-1.4$

$--$

0.7

0.9

South Carolina

2.3

$-3.3$

1.3

$-2.7$

Tennessee

\section{7}

$-0.2$

--.

$-4.1$

$-2.9$

Texas

$-1.5$

1.0

$-4.0$

$-2.9$

9.0

\section{Average Across}

4.2

$-2.4$

0.3

$-0.8$

$-0.5$

0.8

\section{All Twelve States}

Notes: Values in table reflect average annual deviation in a state's growth rate in per capita prison population from the national average. The average across the states reported in the bottom row of the table reflects the fact that different states satisfy the various litigations categories for different numbers of years, and thus is not a simple average of the table entries. For definitions of litigation status categories and the years that each state fall under that category, see Table 1. The twelve states included in the table reflect all states that have had their entire prison system under court order concerning overcrowding at some point between 1971-1993. Prison populations are computed at end of each year. Litigation status in a particular year based on information reported in the ACLU National Prison Project Journal (multiple issues) and the court opinions cited therein. 
Table 4: Short-Run Response of Prison Populations and Crime

to Changes in Prison Overcrowding Litigation Status

Percent Annual Deviation from National Average Growth Rate

Litigation

Status

Pre-filing

Year of Status Change

Filing

Preliminary

Decision

Final

Decision

Further Court

Action

Released from

Court Control

Two or Three Years

Following Status Change

Filing

Preliminary

Decision

Final

Decision

Further Court

17

1.3

$-1.6$

$-0.9$

Action

Released from

6

Prison
Population

2.3

2.7

$-4.4$

$-0.5$

1.8

4.4

$-5.1$

3.6

0.5

9

$-3.2$

4.2

3

5.2

$-0.5$

17

8

$-0.2$

2.7

4.1

18

$-4.6$

3.3

2.5

Court Control

Notes: Data covers the period 1971-1993. Based on data from the twelve states with their entire prison system under court order. Litigation status categories are mutually exclusive; i.e., a second status change within three years overrides the previous status change. Prisoner populations computed at end of year; crime rates correspond to the following year. Figures in table computed using only data within three years of a change in litigation status. Litigation status in a particular year based on information reported in the ACLU National Prison Project Journal (multiple issues) and the court opinions cited therein. Not all states fall into all litigation status categories. 
(1) (2)

\% $\Delta$ Prinon Population

Variable

3 Years Pre-Filing

$.016 \quad-.002$

(.016)

(.018)

Year of Status Chenge:

Filing

Preliminary

Decision

Final

Decision

Purther Court

Action

Reieased from

Court Control

Two to Three Years After Status Change:

Filing

Preliminary

Decision

Final

Decision

Further Court

Action

Released from

Court Control

\% $\Delta$ Income per capita

$\Delta$ Unemployment Rate

\% $\Delta$ Police

$\Delta \%$ Black

$\Delta \%$ Metro

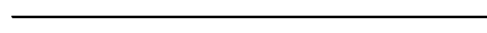

Age Controls?

Year Controls?

State Controls?

$\mathrm{R}^{2}$

P-Value: All Status Changes

P-Value: Status Change This Year $\neq$ 2-3 Years After Stutus Changes

$\begin{array}{ll}.021 & .004 \\ (.019) & (.021)\end{array}$

$\begin{array}{rr}.047 & .041 \\ (.019) & (.022)\end{array}$

(.018)

(.019)

(.018) (.019)

$-.000$

(.015)

$-.010$

-.002
$(.013)$

-.452
$(.180)$

(.179)
(3)

(4)

(5)

(6)

$\$ \Delta$ Violent Crime

\$ $\Delta$ Property Crime

$.005 \quad .002$

(.018) $\quad(.020)$

.001

(.013)

.002

$-.030 \quad-.031$

(.022) (.025)

$-.009$

(.019)

$-.007$

$.023 \quad .021$

$\begin{array}{ll}.023) & (.022)\end{array}$

$-.014$

(.024)

.040

.042

(.030)

$-.002$

(.013)

$-.002$

$\begin{array}{cc}.031 & .030 \\ (.018) & (.019)\end{array}$

(.018)

$-.017$

$-.008$

(.017)

(.020)

$-.013$

(.007)

(.011)

.000

(.013)

.001

(.013)

.003

(.011)

.003

.006

(.026)

.002

(.026)

.032

(.014)

.036

.037

(.013)

(.013)

.033

(.014)

033

$-.016$

$-.019$

(.018)

$-.015$

(.007)

(.011)

(.017)

$-.020$

.060

(.016)

.051

(.018)

$-.009$

(.016)

$(.009)$

.038

.044

(.202)

.127

(.093)

$-.114$

(.194)

$-.026$

$-1.017$

$-.988$

(.361)

(.364)

$\begin{array}{ll}-.064 & -.071\end{array}$

(.054) (.053)

.029

(.032)

$-.037$

(.018)

$(.027) \quad(.060)$

.003

(.006)

.006

$\begin{array}{ll}.0013) & .021 \\ & (.032)\end{array}$

(.011)

Yea Ye

$\begin{array}{cc}\text { Yes } & \text { Yes } \\ \text { Yes } & \text { Yes } \\ \text { No } & \text { Yes } \\ .593 & .614 \\ .002 & .002 \\ .214 & .204\end{array}$

Notes: Data set comprised of annual state level data from 1971-1993. Dependent variable is $\% \Delta$ in state priscon population, $\% \Delta$ in violent crime rate, or $\% \Delta$ in property crime rate depending on the column. Number of observations equal to 1,120 in all columns. Percent changes are computed as $\Delta$ h of variables. Prison overerowding litigation varisbles are indicators corresponding to whether prison litigation atatus has changed in the current year, or two to three years earlier. Prison overcrowding litigation status refers only to states whose entire prison system is under court control. Litigation indicators are mutually exchsive. The omitted litigation categories are four or more years prior to filing and four or more years since last litigation status change. For definitions of status catcgories see text. Prison populations are as of December 31 st; crime rates are the number of UCR crimes for the entire year. 
Table 6: The Impact of Prison Populations on Aggregate Crime Categories

\% $\Delta$ in Violent Crime

Variable

\% $\Delta$ Prison Population

$\% \Delta$ Income per capita

$\Delta$ Unemployment Rate

\% $\Delta$ Police

$\Delta \%$ Black

$\Delta \%$ Metro

$\Delta \%$ Age $0-14$

$\Delta \%$ Age $15-17$

$\Delta \%$ Age 18-24

$\Delta \%$ Age 25-34

Age Controls?

Year Controls?

Stute Controls?

Instrument?

$\mathbf{R}^{2}$

P-Value: Overidentifying Restrictions

IV IV

(2)

(3)

$-.379$

(.180)

.410

(.127)

.451

(.302)

.063

(.048)

.007

(.058)

.027

(.021)

$-.127$

(.447)

.180

(.226)

.286

(.253)

.828

(.350)
\% $\Delta$ Property Crime

FOLS

IV

IV

(4)

(5)

(6)

$-.071$

(.019)

$-.321$

(.138)

$-.261$

(.117)

$\begin{array}{lll}.014 & .076 & .055\end{array}$

$\begin{array}{lll}(.066) & (.072) & (.070)\end{array}$

$\begin{array}{lll}1.032 & 1.138 & 1.063\end{array}$

(.186) (.188) (.181)

$\begin{array}{rrr}-.004 & .012 & .002\end{array}$

$\begin{array}{lll}(.033) & .030) & (.029)\end{array}$

$\begin{array}{lll}-.043 & -.038 & .000\end{array}$

$\begin{array}{lll}(.016) & (.016) & (.035)\end{array}$

$\begin{array}{lll}.006 & -.000 & .005\end{array}$

$(.006) \quad(.006) \quad(.011)$

$\begin{array}{lll}.220 & .121 & .399\end{array}$

(.230) (.234) (.257)

$\begin{array}{lll}.351 & .320 & .390\end{array}$

(.119) (.121) (.127)

$\begin{array}{lll}.277 & .079 & .126\end{array}$

(.141) (.139)

$\begin{array}{lll}.384 & .354 & .436\end{array}$

$\begin{array}{lll}(.187) & (.195) & (.202)\end{array}$

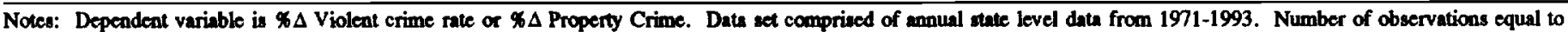
1,063 in all columns. In all cases, eatimation allows for heteroskedasticity acrose states. In cohmms 2 and 5 , five dummy variables corresponding to a change in prison

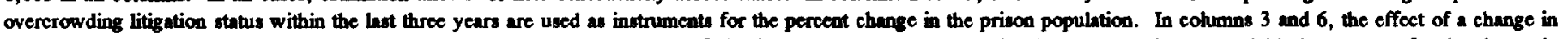

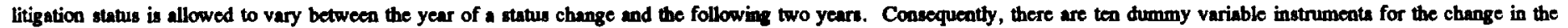

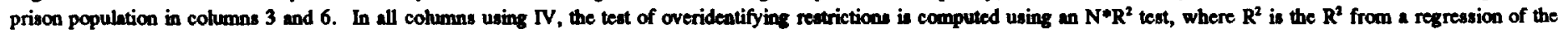

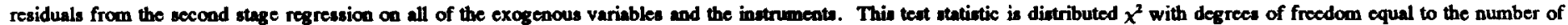

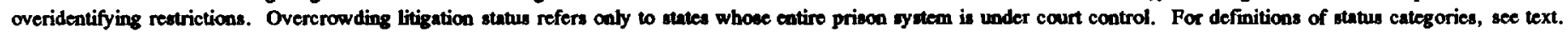
Percent changes are computed as $\Delta \mathrm{ln}$ of variables. Prison populations are for December 31 at; crime rates are the number of $U C R$ crimes for the entire year. 
Table 7: The Impact of Prison Populations on Specific Crime Categories Instrumenting with changes in Prison Overcrowding Litigation Status

\begin{tabular}{|c|c|c|c|c|c|c|c|}
\hline Variable & $\underline{\text { Murder }}$ & $\underline{\text { Rape }}$ & Assault & $\underline{\text { Robbery }}$ & Burglary & Larceny & $\begin{array}{l}\text { Motor Vehicle } \\
\text { Theft }\end{array}$ \\
\hline \% $\Delta$ Prison Population & $\begin{array}{l}-.147 \\
(.373)\end{array}$ & $\begin{array}{l}-.246 \\
(.250)\end{array}$ & $\begin{array}{l}-.410 \\
(.249)\end{array}$ & $\begin{array}{l}-.703 \\
(.309)\end{array}$ & $\begin{array}{l}. .401 \\
(.172)\end{array}$ & $\begin{array}{l}-.277 \\
(.147)\end{array}$ & $\begin{array}{l}-.259 \\
(.235)\end{array}$ \\
\hline$\% \Delta$ Income per capita & $\begin{array}{c}.851 \\
(.300)\end{array}$ & $\begin{array}{l}.281 \\
(.168)\end{array}$ & $\begin{array}{r}.434 \\
(.157)\end{array}$ & $\begin{array}{l}.359 \\
(.191)\end{array}$ & $\begin{array}{l}.000 \\
(.095)\end{array}$ & $\begin{array}{l}.052 \\
(.076)\end{array}$ & $\begin{array}{l}.561 \\
(.127)\end{array}$ \\
\hline$\Delta$ Unemployment Rate & $\begin{array}{l}-.762 \\
(.629)\end{array}$ & $\begin{array}{l}.370 \\
(.384)\end{array}$ & $\begin{array}{l}.332 \\
(.371)\end{array}$ & $\begin{array}{l}.788 \\
(.450)\end{array}$ & $\begin{array}{l}1.327 \\
(.243)\end{array}$ & $\begin{array}{l}1.051 \\
(.200)\end{array}$ & $\begin{array}{l}.851 \\
(.339)\end{array}$ \\
\hline \$ $\Delta$ Police & $\begin{array}{l}-.081 \\
(.097)\end{array}$ & $\begin{array}{l}-.012 \\
(.060)\end{array}$ & $\begin{array}{l}.104 \\
(.058)\end{array}$ & $\begin{array}{l}.011 \\
(.071)\end{array}$ & $\begin{array}{l}.001 \\
(.038)\end{array}$ & $\begin{array}{l}.019 \\
(.031)\end{array}$ & $\begin{array}{l}. .040 \\
(.052)\end{array}$ \\
\hline$\Delta \%$ Black & $\begin{array}{l}-.015 \\
(.048)\end{array}$ & $\begin{array}{l}-.007 \\
(.033)\end{array}$ & $\begin{array}{l}-.022 \\
(.029)\end{array}$ & $\begin{array}{l}-.042 \\
(.036)\end{array}$ & $\begin{array}{l}-.036 \\
(.020)\end{array}$ & $\begin{array}{l}-.034 \\
(.017)\end{array}$ & $\begin{array}{l}-.075 \\
(.027)\end{array}$ \\
\hline$\Delta \%$ Metro & $\begin{array}{l}-.012 \\
(.027)\end{array}$ & $\begin{array}{l}.011 \\
(.016)\end{array}$ & $\begin{array}{l}-.004 \\
(.015)\end{array}$ & $\begin{array}{l}-.017 \\
(.017)\end{array}$ & $\begin{array}{l}.008 \\
(.008)\end{array}$ & $\begin{array}{l}-.003 \\
(.007)\end{array}$ & $\begin{array}{l}-.011 \\
(.011)\end{array}$ \\
\hline$\Delta \%$ Age $0-14$ & $\begin{array}{l}. .074 \\
(.830)\end{array}$ & $\begin{array}{r}-1.079 \\
(.514)\end{array}$ & $\begin{array}{l}.101 \\
(.483)\end{array}$ & $\begin{array}{l}-.441 \\
(.570)\end{array}$ & $\begin{array}{l}.107 \\
(.308)\end{array}$ & $\begin{array}{l}-.038 \\
(.245)\end{array}$ & $\begin{array}{r}.906 \\
(.400)\end{array}$ \\
\hline$\Delta \times$ Age $15-17$ & $\begin{array}{r}.849 \\
(.445)\end{array}$ & $\begin{array}{l}.198 \\
(.270)\end{array}$ & $\begin{array}{l}-.074 \\
(.251)\end{array}$ & $\begin{array}{l}.441 \\
(.298)\end{array}$ & $\begin{array}{l}.411 \\
(.159)\end{array}$ & $\begin{array}{l}.252 \\
(.127)\end{array}$ & $\begin{array}{l}.376 \\
(.205)\end{array}$ \\
\hline$\Delta \%$ Age $18-24$ & $\begin{array}{l}-.364 \\
(.512)\end{array}$ & $\begin{array}{l}-.011 \\
(.310)\end{array}$ & $\begin{array}{c}.372 \\
(.290)\end{array}$ & $\begin{array}{c}.291 \\
(.343)\end{array}$ & $\begin{array}{l}-.101 \\
(.180)\end{array}$ & $\begin{array}{r}.052 \\
(.147)\end{array}$ & $\begin{array}{c}.846 \\
(.240)\end{array}$ \\
\hline$\Delta \%$ Age $25-34$ & $\begin{array}{l}1.165 \\
(.721)\end{array}$ & $\begin{array}{l}.146 \\
(.428)\end{array}$ & $\begin{array}{l}.576 \\
(.408)\end{array}$ & $\begin{array}{l}1.151 \\
(.483)\end{array}$ & $\begin{array}{r}.465 \\
(.255)\end{array}$ & $\begin{array}{c}.111 \\
(.204)\end{array}$ & $\begin{array}{l}1.467 \\
(.339)\end{array}$ \\
\hline Age Controls? & Yes & Yes & Yes & Yes & Yes & Yes & Yes \\
\hline Year Controls? & Yes & Yes & Yes & Yes & Yes & Yes & Yes \\
\hline $\begin{array}{c}\text { P-Value: Overidentifying } \\
\text { Restrictions }\end{array}$ & .816 & .745 & .396 & .125 & .201 & .505 & .386 \\
\hline \multicolumn{8}{|l|}{ - } \\
\hline $\begin{array}{l}\text { Coefficient on } \% \Delta \text { Prison } \\
\text { Population w/o Instrumenting }\end{array}$ & $\begin{array}{l}-.138 \\
(.117)\end{array}$ & $\begin{array}{l}-.015 \\
(.057)\end{array}$ & $\begin{array}{l}. .075 \\
(.057)\end{array}$ & $\begin{array}{l}-.115 \\
(.071)\end{array}$ & $\begin{array}{l}-.124 \\
(.025)\end{array}$ & $\begin{array}{l}-.035 \\
(.022)\end{array}$ & $\begin{array}{l}-.081 \\
(.039)\end{array}$ \\
\hline
\end{tabular}

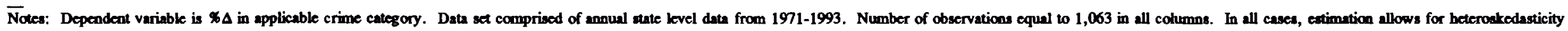

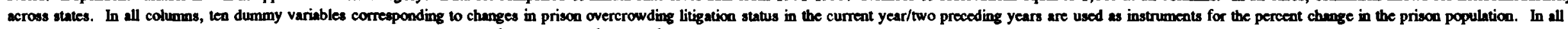

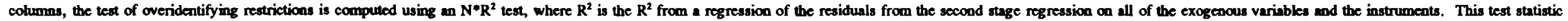

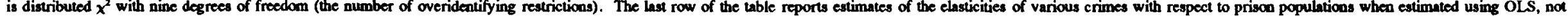

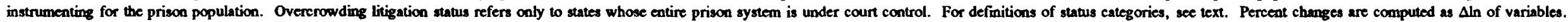

Prison populations are for December 31 st; crime rates are the number of UCR crimes for the entire year. 
Table 8: Estimated Impact On Crime From Adding One Additional Prisoner

(Evaluated at 1993 Sample Mean)

\begin{tabular}{|c|c|c|c|c|}
\hline & $\begin{array}{l}\text { Change in Total } \\
\text { Crime (Assumes }\end{array}$ & Cost & rime & \\
\hline $\begin{array}{c}\text { Change in } \\
\text { Reported Crimes }\end{array}$ & $\begin{array}{l}\text { Same Elasticity for } \\
\text { Unreported Crimes) }\end{array}$ & Monetary & $\begin{array}{l}\text { Quality } \\
\text { of Life }\end{array}$ & $\begin{array}{l}\text { of Reduced } \\
\text { Crime }\end{array}$ \\
\hline
\end{tabular}

$\begin{array}{lccccc}\text { Murder } & -0.004 & -0.004 & \$ 17,000 & \$ 400,000 & \$ 1,800 \\ \text { Rape } & -0.031 & -0.053 & 9,800 & 40,800 & 2,700 \\ \text { Assault } & -0.55 & -1.2 & 1,800 & 10,200 & 14,000 \\ \text { Robbery } & -0.55 & -1.1 & 2,900 & 14,900 & 17,800 \\ \text { Burglary } & -1.3 & -2.6 & 1,200 & 400 & 4,300 \\ \text { Larceny } & -2.6 & -9.2 & 200 & 0 & 1,800 \\ \text { Auto Theft } & -0.5 & -0.7 & 4,000 & 0 & 2,500 \\ & & & & & \\ \text { Total } & -5.54 & -14.86 & -- & -- & 44,900\end{array}$

Notes: Based on estimates of elasticity of crime with respect to prison population by individual crime category from Table 7 (instrumenting with indicator variables for change in prison overcrowding litigation status in current year, and in preceding two years). Values in table are computed using sample means in 1993. Estimates of reporting rates for each type of crime are based on Criminal Victimization in the United States, 1991 (Wash, DC: U.S. Dept. of Justice, 1992), p. 102. With the exception of the quality of life reduction per murder, estimates of the social costs of crime are from Cohen (1988) and Miller, Cohen, and Rossman (1993), adjusted to 1992 dollars. The final column applies the cost of crime to the reduction in combined reported and unreported crime in column 2. 


\section{Definitions of the Uniform Crime Reports Crime Categories}

Murder and Nonnegligent Manslaughter

The willful killing of one human being by another. Deaths caused by negligence, attempts to kill, assaults to kill, suicides, accidental deaths, and justifiable homicides are excluded. Justifiable homicides are limited to the killing of a felon. Traffic fatalities are excluded.

\section{Forcible Rape}

The carnal knowledge of a female forcibly and against her will. Included are rapes by force and attempts or assaults to rape. Statutory offenses (no force used -- victim under age of consent) are excluded.

Robbery

The taking or attempting to take anything of value from the care, custody, or control of a person or persons by force, or threat of force, or violence, and/or by putting the victim in fear.

\section{Aggravated Assault}

An unlawful attack by one person upon another for the purpose of inflicting severe or aggravated bodily injury. This type of assault usually is accompanied by the use of a weapon or by means likely to produce death or great bodily harm. Simple assaults are excluded.

Burglary

The unlawful entry of a structure to commit a felony or a theft. Attempted forcible entry is included.

\section{Larceny}

The unlawful taking of property from the possession of another. Examples are thefts of bicycles or automobile accessories, shoplifting, pocket-picking, or the stealing of any property or article which is not taken by force and violence or by fraud. Attempted larcenies are included. Embezzlement, "con" games, forgery, and worthless checks are excluded.

Motor Vehicle Theft

The theft or attempted theft of a motor vehicle. 


\section{References}

Bane, Mary Jo, 1986, "Household Composition and Poverty," in Fighting Poverty: What Works and What Doesn't, S. Danziger and D. Weinberg (eds.), Cambridge: Harvard University Press.

Bowker, L.H., 1981, "Crime and the Use of Prisons in the United States: A Time Series Analysis," Crime and Delinquency 27:206-212.

Cantor, David, and Kenneth C. Land, 1985, "Unemployment and Crime Rates in the PostWorld War II United States: A Theoretical and Empirical Analysis," American Sociological Review 50:317-332.

Cavanagh, David, and Mark Kleiman, 1990, "A Cost-Benefit Analysis of Prison Cell Construction and Alternative Sanctions," Washington, D.C.: National Institute of Justice.

Cohen, Mark, 1988, "Pain, Suffering, and Jury Awards: A Study of the Cost of Crime to Victims," Law and Society Review 22:537-555.

Dilulio, John, and Anne Piehl, 1991, "Does Prison Pay? The Stormy National Debate over the Cost-Effectiveness of Imprisonment," The Brookings Review (fall), 28-35.

Donohue, John, and Peter Siegelman, 1994, "Is the United States at the Optimal Rate of Crime?" Mimeo, American Bar Foundation.

Ehrlich, Isaac, 1981, "On the Usefulness of Controlling Individuals: An Economic Analysis of Rehabilitation, Incapacitation, and Deterrence, American Economic Review 71:307-322.

Feldstein, Martin, 1995, "Tax Avoidance and the Deadweight Loss of the Income Tax, " NBER Working Paper No. 5055.

Grogger, Jeff, 1994, "Criminal Opportunities, Youth Crime, and Young Men's Labor Supply," Mimeo, University of California at Santa Barbara.

Koren, Edward, 1993, "Status Report: State Prisons and the Courts: January 1, 1993," National Prison Project Journal 8:3-11.

Levitt, Steven, 1994, "Using Electoral Cycles in Police Hiring to Estimate the Effect of Police on Crime," Mimeo, Harvard University.

Levitt, Steven, 1995a, "Why do Higher Arrest Rates Reduce Crime: Deterrence, Incapacitation, or Measurement Error?" Mimeo, Harvard University.

Levitt, Steven, 1995b, "The Response of Crime Reporting Behavior to Changes in the Size of the Police Force: Implications for Studies of Police Effectiveness using Reported Crime 
Data," Mimeo, Harvard University.

Marvell, Thomas, and Carlisle Moody, 1994, "Prison Population Growth and Crime Reduction," Journal of Quantitative Criminology 10:109-140.

Miller, Ted, Mark Cohen, and Shelli Rossman, 1993, "Victim Costs of Violent Crime and Resulting Injuries," Health Affairs XX:186-197.

Model, Karyn, 1993, "The Effect of Marijuana Decriminalization on Hospital Emergency Room Drug Episodes: 1975-1978," Journal of the American Statistical Association 88:737-747.

Nagel, William, 1977, "On Behalf of a Moratorium on Prison Construction," Crime and Delinquency 23:152-174.

Peterson, M.A. and H.B. Braiker, 1980, Doing Crime: A Survey of California Prison Inmates, Rand Corporation: Santa Monica, CA.

Piehl, Anne, and John Dilulio, 1995, "Does Prison Pay? Revisited," The Brookings Review, (winter), 21-25.

Rogers, Joseph, 1989, "The Greatest Correctional Myth," Federal Probation 53:21-28.

Schelling, Thomas, 1989, "Value of Life," in Eatwell, J, Milgate, M., and Newman, P. (eds), The New Palgrave, New York: Norton.

Schmidt, Peter, and Anne Witte, 1989, "Predicting Criminal Recidivism Using 'Split Population' Survival Time Models," Journal of Econometrics 40:141-159.

Selke, William, 1993, Prisons in Crisis, Bloomington: Indiana University Press.

Spelman, W., 1994, Criminal Incapacitation, Plenum Press: New York.

Visher, C.A., 1986, "The RAND Inmate Survey: A Reanalysis, " in Blumstein, A. et al. (eds.), Criminal Careers and "Career Criminals," Volume II, National Academy Press: Washington, D.C.

Waldfogel, Joel, 1993, "Criminal Sentences as Endogenous Taxes: Are They 'Just' or 'Efficient'?" Journal of Law and Economics 36:139-151.

Waldfogel, Joel, 1994, "Does Conviction Have a Persistent Effect on Income and Employment," International Review of Law and Economics 14:103-119.

Wilson, James Q., 1994, "Prisons in a Free Society," The Public Interest 117:37-38.

Zimring, Franklin, and Gordon Hawkins, 1991, The Scale of Imprisonment, University of Chicago Press: Chicago. 